\title{
Nanokitosan Efektif Menekan Jumlah Bakteri Gram Negatif dan Gram Positif Penyebab Endometritis pada Sapi Friesian Holstein secara In Vitro
}

\author{
(NANOCITOSAN EFFECTIVELY SUPPRESSES BACTERIA \\ GRAM NEGATIVE AND GRAM POSITIVE CAUSES OF ENDOMETRITIS \\ IN FRIESIAN HOLSTEIN COW IN VITRO) \\ Edelina Sinaga ${ }^{1}$, Ni Wayan Kurniani Karja ${ }^{1,2}$, Andriani $^{3}$, Amrozi $^{1,2^{*}}$ \\ ${ }^{1}$ Program Studi Biologi Reproduksi, Sekolah Pascasarjana; \\ ${ }^{2}$ Divisi Reproduksi dan Kebidanan, \\ Departemen Klinik, Reproduksi dan Patologi \\ Fakultas Kedokteran Hewan, Institut Pertanian Bogor \\ Jl. Agathis Kampus IPB Dramaga, Bogor, Jawa Barat, Indonesia 16680 \\ ${ }^{3}$ Balai Besar Penelitian Veteriner, \\ Jl RE Martadinata No 30 Bogor, Jawa Barat, Indonesia 16114 \\ Email: amrozi217@gmail.com
}

\begin{abstract}
This study was conducted to isolate and identify the caused bacteria of endometritis in Frisian Holstein $(\mathrm{FH})$ and assessed the effectiveness of nanochitosan against bacterial endometritis in vitro. Sample was collected from six FH cows with subclinical endometritis was examined by ultrasonography, then was calculated the number of colonies, isolation and identification of bacteria. Nanochitosan was calculated the protein content and made into neutral $\mathrm{pH}$ with concentrations of $0,5 \%, 1 \%$ and $2 \%$. The results showed that the highest total plate count in the endometrial fluid was founded at number 626 with 4,7 $\pm 0,6 \mathrm{Log}$ cells $/ \mathrm{mL}$ and the lowest was found at number 532 with 3,3 $\pm 0,8 \mathrm{Log}$ cells $/ \mathrm{mL}$. Bacteria in the Endometritis fluid was founded Gram-negative bacteria were Escherichia coli, Pseudomonas aeruginosa, and Klebsiella sp. Furthermore, Gram-positive bacteria were founded Staphylococcus aureus, Bacillus sp. and $S$. pyogenes. The challenge test of nanochitosan $1 \%$ and $2 \%$ with $E$. coli showed insignificant results when compared with positive controls $(\mathrm{P}>0,05)$. Nanochitosan with all concentrations can reduced number colonies of $P$. aeruginosa and Bacillus sp. significantly compared with negative controls $(\mathrm{P}<0,05)$. The challenge test of nano chitosan $0,5 \%$ and $2 \%$ were able to reduced the number of S. aureus and Klebsiella sp. colonies but could not reduce of $S$. pyogenes. These findings showed treatment of nanochitosan as an antibacterial is able to reduce the number of E. coli, Klebsiella sp. and P. aeruginosa and Bacillus sp. and S. aureus
\end{abstract}

Keywords: bacteria; endometritis; FH cows; in vitro; nanochitosan

\begin{abstract}
ABSTRAK
Penelitian ini bertujuan untuk mengisolasi dan mengidentifikasi bakteri penyebab endometritis pada sapi Frisian Holstein $(\mathrm{FH})$ serta menganalisis efektivitas nanokitosan secara in vitro terhadap bakteri penyebab endometritis. Sampel dikoleksi dari enam ekor sapi FH yang mengalami endometritis subklinis setelah dilakukan pemeriksaan dengan ultrasonografi/USG, kemudian dilakukan perhitungan jumlah koloni, isolasi dan identifikasi bakteri. Nanokitosan diukur kadar proteinnya dan dibuat menjadi $\mathrm{pH}$ netral dengan konsentrasi $0,5 \%, 1 \%$ dan $2 \%$ untuk digunakan pada tahap uji tantang dengan bakteri endometritis yang ditemukan. Hasil penelitian menunjukkan total plate count (TPC) pada cairan endometrium sapi FH paling tinggi terdapat pada sapi perah FH nomor 626 sebanyak 4,7 $\pm 0,6 \mathrm{Log}$ sel/ $\mathrm{mL}$ dan terendah terdapat pada nomor 532 sebanyak 3,3 $\pm 0,8 \mathrm{Log}$ sel/mL. Beberapa bakteri Gram negatif yang ditemukan pada penelitian ini yaitu Escherichia coli, Pseudomonas aeruginosa, dan Klebsiella sp. Bakteri Gram positif yang ditemukan adalah Staphylococcus aureus, Bacillus sp. dan S. pyogenes. Uji
\end{abstract}


tantang nanokitosan pada bakteri E. coli dengan konsentrasi 1\% dan 2\% menunjukkan hasil yang tidak siginifikan jika dibandingkan dengan kontrol positif $(\mathrm{P}>0,05)$. Nanokitosan dengan semua konsentrasi mampu menurunkan jumlah bakteri Klebsiella sp. dan $P$. aeruginosa serta pada bakteri Bacillus sp. secara signifikan jika dibandingkan dengan kontrol negatif $(\mathrm{P}<0,05)$. Uji tantang nanokitosan $0,5 \%$ dan $2 \%$ mampu menurunkan jumlah koloni S. aureus tetapi tidak dapat menurunkan jumlah koloni S. pyogenes. Dapat disimpulkan bahwa pemberian nanokitosan sebagai antibakteri mampu menurunkan jumlah koloni bakteri Gram negatif (E. coli, Klebsiella sp. dan P. aeruginosa) dan Gram positif (Bacillus sp dan $S$. aureus).

Kata-kata kunci: bakteri; endometritis; in vitro; nanokitosan; sapi FH

\section{PENDAHULUAN}

Peradangan uterus (endometritis) dapat disebabkan oleh berbagai mikroorganisme (LeBlanc et al., 2002). Endometritis diklasifikasikan menjadi dua kategori yaitu endometritis klinis (EK) dan endometritis subklinis (ES) (Kasimanickam et al., 2004). Endometritis klinis ditandai dengan adanya leleran/discharge uterus purulen atau mukopurulen yang dapat dideteksi secara eksternal di vagina anterior (LeBlanc et al., 2002; Kasimanickam et al., 2004). Endometritis subklinis sementara itu tidak memperlihatkan adanya tanda-tanda tersebut (Kasimanickam et al., 2004). Endometritis memiliki dampak kerugian ekonomi yang besar bagi peternak, hal tersebut disebabkan karena adanya penurunan keberhasilan reproduksi. Beberapa hal dapat meningkatkan risiko terjadinya endometritis di antaranya adalah kejadian aborsi, kelahiran pada kebuntingan kembar, kerusakan kanal/ jalan kelahiran, kelanjutan kasus distokia atau retensi plasenta, dan kegiatan inseminasi buatan yang tidak lege artist (Ball dan Peters, 2004). Banyak mikroorganisme yang dapat menyebabkan endometritis pada sapi, di antaranya Arcanobacterium pyogenes, Bacteroides sp., Fusobacterium necrophorum, Escherichia coli, Streptococcus sp., Clostridia sp., Pseudomonas aeruginosa, dan Staphylococcus sp. (Seals et al., 2002; Azawi 2008).

Kejadian endometritis dapat didiagnosis melalui palpasi rektal, isolasi dan identifikasi koloni bakteri, biopsi endometrium, pemeriksaan sitologi dan ultrasonografi. Identifikasi dan perhitungan jumlah bakteri menjadi salah satu alternatif alat diagnosis yang dapat dilakukan, sehingga pengobatan endometritis dapat optimal (DPKH Lampung, 2012). Pengobatan endometritis selama ini dilakukan dengan pemberian antibiotik, namun menurut Murdati (1997) antibiotik diketahui sering berdampak negatif dan menjadi residu yang ditemukan pada susu. Kehadiran residu antibiotik pada susu dapat menyebabkan reaksi alergi, keracunan, dan resistansi antibiotik. Sehingga perlu dilakukan analisis terhadap terapi endometritis menggunakan bahan selain antibiotik, salah satunya adalah menggunakan kitosan.

Kitosan merupakan salah satu jenis polimer alami yang dihasilkan dari proses deasetilasi kitin (Goy et al., 2009). Kitin diproduksi dari limbah hewan bercangkang seperti: udang dan rajungan (pada bagian kulit kepala, kaki dan ekor) serta cangkang kerang (Shahidi dan Abuzaytoun, 2005). Karakteristik kitosan dapat dipengaruhi oleh aktivitas biologisnya, termasuk berat molekul, derajat deasetilasi, bentuk garam (-ve ion), dan bentuk struktural (á, â, ã) (Kean dan Thanou, 2010). Berat molekul dan derajat deasetilasi merupakan faktor utama yang memengaruhi ukuran partikel (Singh et al., 2015). Kitosan mempunyai derajat deasetilasi berkisar antara $70-95 \%$ dan berat molekul yang bervariasi mulai dari 10-1000 kDa (Esmaeili et al., 2010). Semakin kecil ukuran partikel, maka luas permukaan partikel akan semakin besar sehingga meningkatkan kemampuan kitosan sebagai absorben, antijamur, antibakteri (Luis et al., 2011), dan antiparasit (El-Sharif dan Hussain, 2011).

Dua mekanisme utama kitosan dalam menghambat sel mikrob, yaitu melalui sifat polikationiknya (Chung et al., 2004; Je dan Kim, 2006) dan sifat kitosan yang dapat memblokir transkripsi DNA bakteri (Liu et al., 2001; Raafat dan Sahl, 2009). Sifat polikationik kitosan mampu mengganggu metabolisme bakteri melalui interaksi elektrostatik di permukaan sel bakteri (Chung et al., 2004; Je dan Kim, 2006). Kitosan lebih lanjut mampu menembus sel dan memblokir transkripsi DNA sehingga tidak terjadi sintesis RNA dan protein (Liu et al., 2001; Raafat dan Sahl, 2009). Penelitian Jeon et al. (2014) menunjukkan bahwa mikropartikel 
kitosan dengan konsentrasi $0,2 \%$ yang diuji secara in vitro maupun in vivo mampu menurunkan jumlah bakteri $E$. coli pada sapi yang mengalami metritis (Jeon et al., 2014). Menurut Xing et al. (2009) nanokitosan sebagai antibakteri mampu menghambat $E$. coli dan $S$. aureus. Oleh karena itu, perlu dilakukan pengujian efektivitas nanokitosan untuk terapi endometritis pada sapi di Indonesia. Penelitian ini bertujuan untuk mengisolasi dan mengidentifikasi bakteri penyebab endometritis pada sapi Frisian Holstein (FH) serta efektivitas nanokitosan terhadap bakteri endometritis secara in vitro.

\section{METODE PENELITIAN}

\section{Waktu dan Lokasi Penelitian}

Sampel cairan endometrium dikoleksi dari sapi Frisian Holstein di Peternakan Rakyat, Kawasan Usaha Peternakan (Kunak) Cibungbulang, Kabupaten Bogor. Analisis sampel dilakukan di Laboratorium Bakteriologi, Balai Besar Penelitian Veteriner Bogor (BB Litvet).

\section{Tahap I. Preparasi Nanokitosan.}

Sebanyak 20 g nanokitosan (PT. Nanotech Herbal, Serpong, Indonesia) dimasukan ke dalam centrifuge tube steril dan dilakukan uji kadar protein di Balai Besar Pascapanen, Bogor. Nanokitosan yang digunakan untuk pengujian antibakteri dilakukan netralisasi terlebih dahulu pada $\mathrm{pH} 7$.

Konsentrasi nanokitosan yang digunakan untuk uji antibakteri pada penelitian ini adalah $0,5,1$, dan 2\%. Penyiapan nanokitosan dilakukan dengan melarutkan $1 \mathrm{~g}$ nanokitosan dalam $1 \mathrm{~mL} \mathrm{HCl} \mathrm{10 \%} \mathrm{(konsentrasi} \mathrm{nanokitosan}$ adalah $100 \%$ dalam $\mathrm{HCl} 10 \%$ ), kemudian dari sampel nanokitosan tersebut dibuat larutan nanokitosan 10\% dengan menambahkan mili $Q$ water steril. Larutan nanokitosan 0,5, 1, dan 2 $\%$ disiapkan dari larutan kitosan 10\% dengan menambahkan media broth (media Brain Heart Infusion untuk uji bakteri Gram positif dan media Nutrient Broth untuk uji bakteri Gram negatif. $\mathrm{pH}$ dari semua larutan yang digunakan untuk uji kemudian dibuat menjadi pH 7 dengan menambahkan $\mathrm{NaOH} 2 \mathrm{~N}$.

Gentamisin inject diambil $1 \mathrm{~mL}$ dimasukkan ke dalam $19 \mathrm{~mL}$ media broth sebagai kontrol positif. Penisilin-streptomisin inject diambil $1 \mathrm{~mL}$ dimasukkan ke dalam 19 $\mathrm{mL}$ media broth sebagai kontrol positif.
Penilisin-G (MEIJI, Pasuruan, Indonesia) ditimbang sebanyak 0,002 g dan streptomisin sulfate (MEIJI, Pasuruan, Indonesia) sebanyak $0,02 \mathrm{~g}$ kemudian dicampurkan dan dimasukkan ke dalam media broth sebagai kontrol positif, lalu disterilkan selama 15 menit pada suhu 121 ${ }^{\circ} \mathrm{C}$. Nanokitosan $2 \%, 1 \%, 0,5 \%$, gentamisin inject, Penstrep inject, penstrep meiji dimasukkan ke dalam penangas air/waterbath shaker dengan $140 \mathrm{rpm}$ dan $37^{\circ} \mathrm{C}$ selama 24 jam.

\section{Tahap II. Koleksi Sampel}

Koleksi Sampel Cairan Uterus. Sebanyak 10 ekor sapi perah FH diperiksa berdasarkan anamnesis yang diperoleh dokter hewan di Kunak. Sapi tersebut kemudian diperiksa keadaan uterus dengan palpasi per rektal dan dikonfirmasi menggunakan USG untuk peneguhan diagnosis endometritis. Sebanyak enam ekor sapi yang positif endometritis kemudian dikoleksi cairan uterusnya sebagai sampel. Koleksi cairan uterus diawali dengan pencucian bagian perineum sapi, dikeringkan dengan tissue bersih, dan dibilas dengan alkohol. Terhadap sapi tersebut selanjutnya dilakukan flushing menggunakan $\pm 50 \mathrm{~mL}$ larutan $\mathrm{NaCl}$ steril, diirigasi ke dalam lumen uterus, kemudian dilakukan koleksi sampel cairan uterus secara aspirasi menggunakan gun Inseminasi Buatan yang steril. Sampel cairan uterus dikoleksi dengan cara dimasukkan ke dalam centrifuge tube steril dibawa ke Laboratorium Bakteriologi BB Litvet menggunakan cool box suhu $\pm 4{ }^{\circ} \mathrm{C}$ selama enam jam dan disiapkan untuk pengujian selanjutnya isolasi dan identifikasi bakteri.

\section{Tahap III. Uji Mikrobiologi}

Penghitungan Jumlah Koloni Bakteri Sebelum Identifikasi. Cairan uterus yang didapatkan kemudian dicampurkan dengan buffer saline $(1: 9, \mathrm{v} / \mathrm{v})$. Campuran tersebut diencerkan sebanyak enam kali pengenceran. Masing-masing pengenceran diambil $100 \mu \mathrm{L}$ campuran dan dimasukkan ke dalam cawan petri steril. Sebanyak $15 \mathrm{~mL}$ plate count agar $(\mathrm{PCA})$ hangat $\left(44-46^{\circ} \mathrm{C}\right)$ selanjutnya dituangkan ke dalam cawan petri berisi suspensi bakteri yang telah diencerkan sebelumnya. Campuran tersebut kemudian dihomogenkan secara perlahan dan dibiarkan memadat. Cawan petri setelah itu diinkubasi selama 24 jam pada suhu $37^{\circ} \mathrm{C}$. Bakteri yang tumbuh setelah inkubasi 
dihitung jumlah total koloni bakteri dengan tujuan untuk mengetahui keberadaan bakteri dalam sampel yang dikoleksi.

Isolasi dan Identifikasi Bakteri. Isolasi bakteri dilakukan dengan cara memasukkan $200 \mu \mathrm{L}$ cairan uterus di atas permukaan berbagai media kemudian diratakan ke seluruh permukaan menggunakan ose. Adapun media agar yang digunakan adalah Mac Conkey Agar (MCA) untuk menumbuhkan bakteri Gram negatif, media Blood Agar (BA) untuk menumbuhkan bakteri Gram positif dan negatif, dan media Eosin Methylene Blue Agar (EMBA) untuk menumbuhkan bakteri $E$. coli. Cawan petri yang sudah ditanam bakteri kemudian diinkubasikan selama 24 jam pada suhu $37^{\circ} \mathrm{C}$ dengan posisi cawan petri terbalik (untuk mencegah koloni menyebar). Setelah inkubasi, isolat bakteri diamati secara morfologi kemudian koloni yang berbeda dimurnikan dengan Nutrien Agar (NA). Isolat bakteri yang sudah murni kemudian diidentifikasi jenis bakterinya. Identifikasi bakteri dilakukan dengan pengujian motilitas, pewarnaan Gram, uji katalase dan oksidase, dan pengujian terhadap 12 jenis gulagula. Bakteri spesifik yang didapatkan kemudian ditantang dengan nanokitosan.

Tahap IV. Pengujian Efektivitas Nanokitosan sebagai Antibakteri

Preparasi Suspensi Bakteri dan Praperlakuan Efektivitas Nanokitosan. Isolat bakteri yang didapatkan pada tahap sebelumnya selanjutnya diremajakan terlebih dahulu selama 24 jam. Isolat bakteri E. coli, Klebsiella sp., dan $P$. aeruginosa diencerkan bertingkat dari $10^{-1}$ hingga $10^{-5}$ dengan larutan fisiologis steril. Isolat bakteri Bacillus sp., Streptococcus sp., $S$. aureus diencerkan bertingkat dari $10^{-1}$ hingga $10^{-7}$ dengan larutan fisiologis steril. Isolat bakteri tersebut kemudian diuji dengan nanokitosan konsentrasi $0,5 \%, 1 \%$, dan $2 \%$, sebagai kontrol positif digunakan Penilisin-G (Meiji, Pasuruan, Indonesia)-streptomisin sulfate (Meiji, Pasuruan, Indonesia), Genta-100 (TMC, Bandung, Indonesia), dan Pen \& Strep (Norbrook Laboratories Ltd., Newry, Inggris ). Sebanyak $1 \mathrm{~mL}$ gentamisin inject dan penstrep inject dimasukkan ke dalam $19 \mathrm{~mL}$ media broth, masing-masing. Sebanyak $2 \mathrm{mg}$ penisilin dan $0,02 \mathrm{~g}$ streptomisin dicampurkan ke dalam 80 $\mathrm{mL}$ media broth dan disterilkan selama 15 menit $121^{\circ} \mathrm{C}$. Semua sampel perlakuan nanokitosan $0,5 \%, 1 \%, 2 \%$, gentamisin inject, penstrep inject, penstrep meiji dimasukkan ke dalam penangas air/waterbath shaker dengan kecepatan $140 \mathrm{rpm}$ dan suhu $37^{\circ} \mathrm{C}$ selama 24 jam. Kontrol negatif hanya menggunakan media broth yang dicampur dengan bakteri.

Efektivitas Nanokitosan. Sebanyak $1 \mathrm{~mL}$ $E$. coli, Klebsiella sp. dan P. aeruginosa pengenceran $10^{-5}$ dan $10^{-7}$ untuk Bacillus sp., Streptococcus pyogenes dan S. aureus) masingmasing dimasukkan ke dalam labu erlenmeyer ke-1 (media broth sebagai kontrol negatif), labu erlenmeyer ke-2 (gentamisin inject), labu erlenmeyer ke-3 (penisilin-streptomisin Meiji), labu erlenmeyer ke-4 (penisilin-streptomisin inject), labu erlenmeyer ke-5 (nanokitosan 0,5\%), labu erlenmeyer ke-6 (nanokitosan 1\%), labu erlenmeyer ke-7 (nanokitosan 2\%) dan diinkubasi selama satu jam di suhu ruang. Setelah satu jam, sebanyak $1 \mathrm{~mL}$ suspensi (E. coli dan Klebsiella sp, P. aeruginosa dan Bacillus sp.) ketujuh perlakuan, masing-masing dimasukan ke dalam cawan petri dan ditambahkan media PCA dengan menggunakan teknik pour plate serta ( $S$. pyogenes dan $S$. aureus) dengan menggunakan teknik spread plate. Campuran tersebut dibiarkan hingga memadat dan diinkubasi selama 24 jam pada suhu $37^{\circ} \mathrm{C}$ untuk bakteri E. coli, Klebsiella sp., S. aureus, dan $S$. pyogenes, pada $40^{\circ} \mathrm{C}$ untuk Bacillus sp., serta suhu $42^{\circ} \mathrm{C}$ untuk bakteri $P$. aeruginosa dengan posisi cawan petri terbalik. Semua perlakuan setelah inkubasi dilakukan penghitungan terhadap jumlah total koloni bakteri.

\section{Analisis Data}

Penelitian ini menggunakan rancangan acak lengkap (RAL) dengan masing-masing perlakuan terdiri atas empat kali ulangan. Data total plate count efektivitas kitosan terhadap bakteri endometritis dianalisis secara statistika menggunakan sidik ragam/Analysis of Variance pada taraf nyata $95 \%$. Perbedaan yang nyata antar perlakuan, diuji lanjut dengan uji jarak berganda Duncan. Data diolah menggunakan program SPSS versi 24.0.

\section{HASIL DAN PEMBAHASAN}

\section{Karakteristik Nanokitosan}

Aktivitas antimikrob nanokitosan secara in vitro dipengaruhi oleh faktor intrinsik dan ekstrinsik. Faktor intrinsik di antaranya jenis, berat molekul, derajat deasetilasi, viskositas, ukuran partikel, pelarut dan konsentrasi. 
Adapun faktor ekstrinsik di antaranya yaitu strain uji, keadaan fisiologis, media kultur bakteri dan pH (Rafaat dan Sahl, 2008). Karakteristik nanokitosan yang digunakan dalam penelitian ini disajikan pada Tabel 1 . Tabel 1 menunjukkan bahwa kitosan yang digunakan merupakan kitosan dengan ukuran 395,3 nm. Menurut Tiyaboonchai (2003), ukuran nanokitosan berkisar antara 1-1000 nm. Menurut Aloys et al. (2016) partikel nanokitosan dengan ukuran antara 100-600 $\mathrm{nm}$ telah dibuat dengan berbagai metode, seperti gelasi ionik (Calvo et al., 1997), emulsi cross-linking (Rieggera et al., 2018), koalesensi tetesan emulsi (Balcerzak et al., 2013), proses reverse micellar (Zhao 2011), dan pengayakan (Agnihotri 2004). Penggunaan nanokitosan diharapkan agar partikel tersebut mampu masuk ke dalam sel dan mendapatkan hasil terapi yang maksimal. Menurut Luis et al. (2011), semakin kecil ukuran partikel kitosan maka luas permukaan partikel semakin besar sehingga meningkatkan kemampuan kitosan sebagai absorben, antijamur, antibakteri. El-Sharif dan Hussain (2011) menambahkan bahwa kitosan dengan ukuran yang kecil mampu berperan sebagai antiparasit. Kadar protein dari nanokitosan

Tabel 1. Karakteristik nanokitosan yang digunakan dalam penelitian

\begin{tabular}{ll}
\hline Parameter & Nanokitosan \\
\hline Ukuran Partikel & $395,3 \mathrm{~nm}$ \\
Kadar Protein & $1,1 \%$ \\
pH awal nanokitosan & 4 \\
pH akhir nanokitosan & 7 \\
\hline
\end{tabular}

sebanyak $1,1 \%$ diukur dengan tujuan untuk menghindari reaksi alergi. Menurut standar mutu kitosan (Protan Laboratorium Inc), kadar protein yang menyebabkan alergi yaitu yang di atas 5\%. Kitosan dari udang mengandung protein tropomiosin dan protein tersebut biasanya menyebabkan reaksi alergi (Liu et al., 2010). Derajat keasaman ( $\mathrm{pH})$ nanokitosan yang didapatkan adalah 4, namun untuk menghindari hasil bias terhadap antibakteri karena sifat asam dari kitosan maka nanokitosan tersebut dinetralkan derajat keasamannya.

\section{Isolasi dan Identifikasi Bakteri dari Cairan Endometrium}

Jumlah koloni dan jenis bakteri yang dapat diisolasi dan diidentifikasi dari cairan endometrium sapi yang mengalami endometritis subklinis disajikan pada Tabel 2. Jumlah koloni bakteri atau total plate count (TPC) pada keenam sampel cairan endometrium sapi $\mathrm{FH}$ paling tinggi terdapat pada sapi nomor 626 yaitu sebanyak $4,7 \pm 0,6 \mathrm{Log} \mathrm{sel} / \mathrm{mL}$ dan jumlah koloni bakteri terendah terdapat pada sapi nomor 532 yaitu $3,3 \pm 0,8 \mathrm{Log} \mathrm{sel} / \mathrm{mL}$. Beberapa bakteri Gram negatif, ditemukan pada penelitian ini yaitu E. coli, P. aeruginosa, dan Klebsiella sp. Lebih lanjut, bakteri Gram positif yang ditemukan pada penelitian ini adalah $S$. aureus, Bacillus sp. dan S. pyogenes. Bakteri yang sering ditemukan pada keenam sampel cairan uterus endometritis yaitu Bacillus sp., $P$. aeruginosa, Klebsiella sp. (Seals et al., 2002; Moges et al., 2013; Wagener et al., 2015). Penelitian Liu et al. (2013) melaporkan bahwa Staphylococci merupakan kelompok bakteri patogen dominan $(21,8 \%)$ penyebab endometritis klinis utama yang dapat dideteksi pada sapi

Tabel 2. Total plate count (TPC) dan jenis bakteri dari cairan endometrium sapi yang mengalami endometritis subklinis

\begin{tabular}{|c|c|c|c|c|c|c|c|}
\hline \multirow{2}{*}{$\begin{array}{l}\text { No Sampel } \\
\text { Sapi }\end{array}$} & \multirow{2}{*}{$\begin{array}{l}\text { Total Plate } \\
\text { Count } \\
\text { (Log sel } / \mathrm{mL}) \\
\quad \pm \text { SEM }\end{array}$} & \multicolumn{5}{|c|}{ Bakteri } & \multirow[b]{2}{*}{ S. aureus } \\
\hline & & E. coli & Klebsiella sp. & P. aeruginosa & Bacillus sp. & S.pyogenes & \\
\hline 206 & $4,2 \pm 0,8$ & - & $\mathrm{t}$ & $\mathrm{t}$ & $\mathrm{t}$ & $\mathrm{t}$ & - \\
\hline 312 & $4,2 \pm 0,7$ & $\mathrm{t}$ & $\mathrm{t}$ & $\mathrm{t}$ & $\mathrm{t}$ & - & $\mathrm{t}$ \\
\hline 532 & $3,3 \pm 0,8$ & $\mathrm{t}$ & $\mathrm{t}$ & $\mathrm{t}$ & $\mathrm{t}$ & - & $\mathrm{t}$ \\
\hline 626 & $4,7 \pm 0,6$ & $\mathrm{t}$ & $\mathrm{t}$ & $\mathrm{t}$ & $\mathrm{t}$ & $\mathrm{t}$ & - \\
\hline 820 & $3,4 \pm 1,0$ & $\mathrm{t}$ & $\mathrm{t}$ & $\mathrm{t}$ & $\mathrm{t}$ & $\mathrm{t}$ & - \\
\hline 861 & $4,5 \pm 0,6$ & - & - & $\mathrm{t}$ & $\mathrm{t}$ & - & - \\
\hline
\end{tabular}

Keterangan: t: Ada; -: Tidak ada; SEM: Standard error of measurement 
perah. Williams et al. (2007) lebih lanjut menemukan bahwa $S$. aureus merupakan penyebab utama endometritis klinis pada sapi perah.

\section{Pengujian Efektivitas Nanokitosan sebagai Antibakteri}

Pengujian efektivitas kitosan terhadap bakteri Gram negatif dan positif disajikan pada Tabel 3. Pemberian nanokitosan dengan konsentrasi $1 \%$ dan $2 \%$ mampu menurunkan jumlah bakteri $E$. coli secara signifikan jika dibandingkan dengan kontrol negatif $(\mathrm{P}<0,05)$. Nanokitosan pada konsentrasi $2 \%$ menunjukkan efektivitas yang sama dengan kontrol positif (gentamisin, penstrep powder, dan penstrep inject) $(\mathrm{P}>0,05)$. Uji tantang nanokitosan pada konsentrasi 0,5\% dan 2\% mampu menurunkan jumlah bakteri Klebsiella sp. sebesar 0,1 Log sel/mL, P. aeruginosa dan Bacillus sp. secara signifikan jika dibandingkan dengan kontrol negatif $(\mathrm{P}<0.05)$. Uji tantang nanokitosan $0,5 \%$ dan $2 \%$ mampu menurunkan jumlah koloni $S$. aureus tetapi tidak mampu menurunkan jumlah koloni S. pyogenes.

Pemberian nanokitosan secara in vitro berdasarkan data tersebut menunjukkan bahwa mampu menurunkan jumlah koloni bakteri Gram negatif. Pemberian kitosan terhadap bakteri Gram negatif berfungsi sebagai agen antibakteri secara pasif yaitu dengan mengurangi protein pada permukaan dinding sel yang berfungsi untuk merusak adhesi bakteri (Francolini et al., 2015; Zhang et al., 2015). Hal tersebut menunjukkan bahwa kitosan tidak dapat membunuh bakteri tetapi menghambat bakteri. Proses menghambat bakteri dapat diwujudkan dengan tolakan hidrofilik/ hidrofobik, dan tolakan elektrostatik (Matica et al., 2017). Penelitian Park et al. (2004) dan Du et al. (2009) melaporkan bahwa bakteri Gram negatif lebih rentan terhadap kitosan. Chung et al. (2004) juga mengemukakan bahwa hidrofilisitas bakteri Gram negatif lebih tinggi daripada bakteri Gram positif sehingga sensitif terhadap kitosan. Nanokitosan dengan konsentrasi $2 \%$ mampu secara efektif membunuh bakteri $E$. coli. Bakteri $E$. coli merupakan bakteri Gram negatif yang mempunyai lapisan peptidoglikan tipis (Salton, 1963) sehingga nanokitosan mampu untuk membunuh bakteri dengan memengaruhi Outer membrane (OM) dan Inner membrane (IM) bakteri yang menyebabkan kerusakan struktur, fungsi dan peningkatan permeabilitas membran E. coli (Li et al., 2010). Jeon et al. (2014) menunjukkan bahwa pemberian mikropartikel kitosan pada bakteri E. coli O157: H7 memiliki aktivitas antimikrob yang dapat memengaruhi membran sel bakteri melalui interaksi dengan protein A di membran luar pada $\mathrm{pH}$ netral dan berakhir pada kematian sel bakteri.

Nanokitosan selain itu dapat menurunkan jumlah bakteri Klebsiella sp. yakni Klebsiella pneumonia. Menurut Didenko et al. (2005), kitosan dapat berpengaruh terhadap bakteri $K$. pneumonia karena menyebabkan ketebalan kapsul bakteri menipis dan terjadi fragmentasi lapisan luar pada dinding sel. Pada Tabel 3 ditunjukkan bahwa nanokitosan mampu

Tabel 3. Efektivitas nanokitosan terhadap bakteri Gram negatif dan positif penyebab endometritis*

\begin{tabular}{|c|c|c|c|c|c|c|c|}
\hline \multirow[t]{2}{*}{ Jenis } & \multicolumn{3}{|c|}{ Kontrol Positif(Log sel/mL) } & \multicolumn{3}{|c|}{ Konsentrasi Nanokitosan (Log sel/mL) } & \multirow{2}{*}{$\begin{array}{c}\text { Kontrol } \\
\text { Negatif } \\
(\text { Log sel } / \mathrm{mL})\end{array}$} \\
\hline & Gentamisin & $\begin{array}{l}\text { Penstrep } \\
\text { Powder }\end{array}$ & $\begin{array}{l}\text { Penstrep } \\
\text { Inject }\end{array}$ & $0,5 \%$ & $1 \%$ & $2 \%$ & \\
\hline \multicolumn{8}{|l|}{ Bakteri Gram Negatif } \\
\hline E.coli & $0,0 \pm 0,0^{\text {a }}$ & $0,0 \pm 0,0^{\mathrm{a}}$ & $0,0 \pm 0,0^{\text {a }}$ & $\geq 11,0 \pm 0,0^{\mathrm{d}}$ & $7,9 \pm 0,03^{\mathrm{b}}$ & $0,0 \pm 0,0^{\text {a }}$ & $8,7 \pm 0,0^{c}$ \\
\hline Klebsiella sp. & $0,0 \pm 0,0^{\text {a }}$ & $0,0 \pm 0,0^{\mathrm{a}}$ & $0,0 \pm 0,0^{\text {a }}$ & $8,2 \pm 0,0^{\mathrm{b}}$ & $8,3 \pm 0,03^{c}$ & $8,2 \pm 0,1^{\mathrm{b}}$ & $8,3 \pm 0,0^{c}$ \\
\hline P. aeruginosa & $0,0 \pm 0,0^{\text {a }}$ & $0,0 \pm 0,0^{\mathrm{a}}$ & $0,0 \pm 0,0^{\text {a }}$ & $7,4 \pm 0,0$ bc & $7,4 \pm 0,04^{\mathrm{c}}$ & $7,3 \pm 0,0^{\mathrm{b}}$ & $8,5 \pm 0,0^{\mathrm{d}}$ \\
\hline $\begin{array}{l}\text { Bakteri Gram positif } \\
\text { Bacillus sp. }\end{array}$ & $0,0 \pm 0,0^{\mathrm{a}}$ & $0,0 \pm 0,0^{\mathrm{a}}$ & $0,0 \pm 0,0^{\mathrm{a}}$ & $0,0 \pm 0,0^{\mathrm{a}}$ & $\geq 4,0 \pm 2,30^{\mathrm{a}}$ & $4,1 \pm 2,4^{\text {a }}$ & $\geq 10,8 \pm 0,0^{b}$ \\
\hline S. aureus & $0,0 \pm 0,0^{\text {a }}$ & $0,0 \pm 0,0^{\mathrm{a}}$ & $0,0 \pm 0,0^{\text {a }}$ & $>8,7 \pm 0,4^{\mathrm{b}}$ & $\geq 11,0 \pm 0,0^{\mathrm{c}}$ & $>8,8 \pm 0,3^{\mathrm{b}}$ & $\geq 11,0 \pm 0,0^{c}$ \\
\hline S. pyogenes & $0,0 \pm 0,0^{\mathrm{a}}$ & $0,0 \pm 0,0^{\mathrm{a}}$ & $0,0 \pm 0,0^{\mathrm{a}}$ & $\geq 11,0 \pm 0,0^{c}$ & $\geq 11,0 \pm 0,0^{c}$ & $\geq 11,0 \pm 0,0^{\mathrm{c}}$ & $10,6 \pm 0,0^{\mathrm{b}}$ \\
\hline
\end{tabular}

Keterangan: a,b,c,d, pada baris yang sama menunjukkan perbedaan yang nyata $(\mathrm{P}<0.05)$; *Data diulang sebanyak 4 kali, data yang ditampilkan merupakan hasil dari total plate count (TPC) yang telah di Logkan. 
menurunkan jumlah koloni bakteri $P$. aeruginosa. Penelitian Tao et al. (2011) mengemukakan bahwa morfologi membran sel $P$. aeruginosa yang terpapar kitosan $300 \mathrm{mg} / \mathrm{L}$ selama 20 menit dapat mengalami kerusakan. Didenko et al. (2005) juga menyatakan bahwa kerusakan dinding sel pada bakteri dapat menyebabkan penurunan fungsi sel dan proses mitosis yang mengakibatkan kematian sel.

Pada Tabel 3 ditunjukkan bahwa nanokitosan mampu menurunkan jumlah koloni bakteri secara signifikan pada semua konsentrasi pada bakteri Bacillus sp. $(\mathrm{P}<0,05)$. Bacillus sp. merupakan bakteri Gram positif yang memiliki dinding sel terdiri atas lapisan peptidoglikan tebal yang dipenuhi asam teikoat bermuatan negatif karena adanya gugus fosfat (Vollmer et al., 2008). Senyawa bermuatan negatif (protein dan glikoprotein) terdapat di permukaan sel Bacillus sp. berpotensi berinteraksi dengan molekul kitosan bermuatan positif sehingga meningkatkan permeabilitas membran, yang mengarah pada kebocoran zat intraseluler (Chung et al., 2004; Liu et al., 2004).

Bakteri S. pyogenes merupakan bakteri Gram positif. Menurut Prochnow et al. (2016), bakteri Gram positif memiliki struktur dinding sel yang tebal sekitar 20-80 nanometer dan terdiri atas beberapa lapisan peptidoglikan. Bakteri S. pyogenes yang memiliki dinding lapisan peptidoglikan atau sel multilayer murein sehingga nanokitosan tidak bisa melakukan penetrasi ke dalam sel (Rafaat et al., 2009).

Nanokitosan selain itu dapat menurunkan jumlah koloni bakteri S. aureus. Menurut Didenko et al. (2005) bahwa Staphylococcus dengan pemberian kitosan menghasilkan penampilan protoplas (bakteri tanpa dinding sel) yang mengakibatkan lapisan luar membran sitoplasma menjadi terfragmentasi. Pada Tabel 3 ditunjukkan bahwa aktivitas antibakteri kitosan dapat berbeda pada setiap spesies mikrob yang disebabkan oleh beragam kondisi lingkungan (Kong et al., 2010).

\section{SIMPULAN}

Pemberian nanokitosan sebagai antibakteri mampu menurunkan jumlah koloni bakteri Gram negatif (E. coli, Klebsiella sp. dan $P$. aeruginosa) dan Gram positif (Bacillus sp. dan S. aureus).

\section{SARAN}

Dari hasil yang diperoleh pada penelitian ini, disarankan dilakukan uji efektivitas antibakteri nanokitosan terhadap penyembuhan endometritis pada sapi.

\section{UCAPAN TERIMA KASIH}

Penulis mengucapkan terima kasih kepada Dr.drh. Krido Brahmo Putro yang telah membantu dalam pengambilan sampel cairan uterus dan Peternakan Rakyat Kawasan Usaha Peternakan Cibungbulang, Kabupaten Bogor yang telah memberikan izin untuk pengambilan sampel cairan uterus.

\section{DAFTAR PUSTAKA}

Agnihotri SA, Mallikarjuna NN, Aminabhavi TM. 2004. Recent advances on chitosan based micro and nanoparticles in drug delivery. J Control Release 100: 5-28.

Aloys H, Korma SA, Alice TA, Chantal N, Ali AH, Abed SM, Ildephonse H. 2016. Microencapsulation by complex coacervation: methods, techniques, benefits, and applications - A Review. American J Food Sci Nutr Res 3: 188-192.

Azawi OI. 2008. Postpartum uterine infection in cattle. Anim Reprod Sci 105: 187-208.

Ball PJH, Peters AR. 2004. Reproduction in cattle. 3rd edition. Oxford (GB): Blackwell Publishing. Hlm. 124

Balcerzak J, Kucharska M, Gruchaaa B. 2013. Preparation of Micro and Nanostructures of Chitosan by Ultrasonic Coalescence of W/ O Emulsion. Prog Chem Appl Chitin Deriv 18: $13-20$.

Calvo P, Remuñan-Lopez C, Vila-Jato JL, Alonso MJ. 1997. Novel hydrophilic chitosan polyethylene oxide nanoparticles as protein carriers. J Appl Polym Sci 63: 125-132.

Chung Y, Su Y, Chen C, Jia G, Wang H, Wu J. 2004. Relationship between antibacterial activity of chitosan and surface characteristics of cell wall. Acta Pharm Sin 25: 932-936. 
Didenko LV, Gerasimenko DV, Konstantinova ND, Silkina TA, Avdienko ID, Bannikova GE, dan Varlamov VP. 2005. Ultrastructural study of chitosan effect on Klebsiella and Staphylococci. Bull Exp Biol Med 140(3): 360-365.

DPKH Lampung (Dinas Peternakan dan Kesehatan Hewan Lampung). 2012. Buku statistik peternakan. Lampung. Dinas Peternakan dan Kesehatan Hewan Provinsi Lampung.

Du WX, Olsen CW, Avena-bustillos RJ, Mchugh TH, Levin CE, Friedman M. 2009. Storage stability and antibacterial activity against Escherichia coli O157: H7 of carvacrol in edible apple ûlms made by two different casting methods. J Agri Food Chem 56: 3082-3088.

El-Sharif AA, Hussain MH. 2011. ChitosanEDTA new combination is a promising candidate for treatment of bacterial and fungal infections. Curr Microbiol 62: 739745 .

Esmaeili F, Heuking S, Junginger HE, dan Borchard G. 2010. Progress in chitosanbased vaccine elivery systems. J Drug Del Sci Tech 20: 53-61.

Francolini I, Donelli G, Crisante F, Taresco V, Piozzi A. 2015. Antimicrobial polymers for anti biofilm medical devices: state of art and perspectives. Adv Exp Med Biol 831: 93117.

Goy RC, Britto D, Assis OBG. 2009. A review of the antimicrobial activity of chitosan. Polímeros 19: 241-247.

Je J, Kim S. 2006. Chitosan derivatives killed bacteria by disrupting the outer and inner membrane. J Agri Food Chem 54: 66296633.

Jeon SJ, Yeo WS, Galvao KN, Jeong KC. 2014. Underlying mechanism of antimicrobial activity of chitosan microparticles and implications for the treatment of infectious diseases. PLoS ONE 9: 92-723.

Kasimanickam R, Duffield TF, Foster, RA, Gartley CG, Leslie KE, Walton JS, Johnson WH. 2004. Endometrial cytology and ultrasonography for the detection of subclinical endometritis in postpartum dairy cows. Theriogenology 62: 9-23.
Kean T, Thanou M. 2010. Biodegradation, biodistribution and toxicity of chitosan. Adv Drug Deliv 62: 3-11.

Kong M, Chen XG, Xing K, Park HJ. 2010. Antimicrobial properties of chitosan and mode of action: a state of the art review. Int J Food Microbiol 144: 51-63.

LeBlanc SJ, Duffield T, Leslie K, Bateman K, Keefe G, Walton J, Johnson W. 2002. Defining and diagnosing postpartum clinical endometritis, and its impact on reproductive performance in dairy cows. J of Dairy Sci 85: 2223-2236.

Li X, Feng X, Yang S, Fu G, Wang T, Su Z. 2010. Chitosan kills Escherichia coli through damage to be of cell membrane mechanism. Carbohydr Polym 79(3): 493499.

Liu X, Yun L, Dong Z, Zhi L, Kang D. 2001. Antibacterial action of chitosan and carboxymethylated chitosan. $J$ of $A p p l$ Polym Sci 79(7): 1324-1335.

Liu GM, Cheng H, Nesbit JB, Su WJ, Cao MJ, Maleki SJ. 2010. Effects of boiling on the ige-binding properties of tropomyosin of shrimp (Litopenaeus vannamei). J Food Sci 75(1): T1-T5.

Liu CJ, Wang YH, Yang ZH, Cao YG, Li DP, Liu WB, Zhang NS. 2013. Prevalence and major pathogen causes of dairy cows clinical endometritis in northeast china. Asian J Anim Vet Adv 8: 124-129.

Luis E, Anton R, Kenneth AH, Duncan S, Peter L. 2011. Antimicrobial effect of chitosan nanoparticles on streptococcus mutans biofilm. J Appl environ microb 77: 3892 3895 .

Matica A, Menghiu G, Ostafe V. 2017. Antibacterial Properties of Chitin and Chitosans. New Front in Chem Rev 27: 3954 .

Moges N, Regassa F, Yilma T, Unakal GC. 2013. Isolation and antimicrobial susceptibility of bacteria from dairy cows with clinical endometritis. J Reprod Infertil 4: 4-8.

Murdiati TB. 1997. Pemakaian antibiotik dalam usaha peternakan. Wartazoa 6: 1-5. 
Park SI, Daeschel MA, Zhao Y. 2004. Functional properties of antimicrobial lysozyme chitosan composite films. J Food Sci 69: 215-221.

Prochnow M, Clauson A, Hong M, Murphy J. 2016. Gram positive and Gram negative bacteria differ in their sensitivity to cold plasma. Sci Reports 6: 1-11.

Raafat D, Kristine VB, Albert H, Hans GS. 2008. Insights into the mode of action of chitosan as an antibacterial compound. Appl Environ Microb 74: 3764-3773.

Raafat D, Sahl HG. 2009. Chitosan and its antimicrobial potential a critical literature survey. Microb Biotechnol 2: 186-201.

Rieggera BR, Bäurera B. Mirzayevaa A, Tovara GEM, Bach. 2018. A systematic approach of chitosan nanoparticle preparation via emulsion crosslinking as potential adsorbent in wastewater treatment. Carbohydr Polym 180: $46-54$.

Salton MRJ. 1963. The relationship between the nature of the cell wall and gram stain. $J$ Gen Microbial 30: 223-235.

Seals RC, Matamoros I, Lewis GS, 2002. Relationship between postpartum changes in 13,14-dihydro-15-keto-PGF2 concentrations in Holstein cows and their susceptibility to endometritis. J Anim Sci 80: 1068-1073.

Shahidi F, Abuzaytoun R. 2005. Chitin, chitosan, and co-products: chemistry, production, application, and health effects. Adv Food Nutr 49: 93-135.

Singh D, Shashi A, Alok M, Kushal K. 2015. Advancement of ChitosanBased Nanoparticles for Targeted Drug Delivery of Antiulcer Drugs. Int J Pharm Pharm Sci 4: 505-518.
Tao Y, Qian LH, Xie J. 2011. Effect of chitosan on membrane permeability and cell morphology of Pseudomonas aeruginosa and Staphyloccocus aureus. Carbohydr Polym 86: 969-974.

Tiyaboonchai W. 2003. Chitosan Nanoparticles: A Promising System for Drug Delivery. $J$ Naresuan University 11: 51-66.

Vollmer W, Blanot D, Miguel A, Pedro de. 2008. Peptidoglycan structure and architecture. Microbiol Rev 32: 149-167.

Wagener K., Prunner I., Pothmann H, Drillich M, Schulz EM. 2015. Miversity and health status speciûc ûuctuations of intrauterine microbial communities in postpartum dairy cows. Vet Microbiol 175: 286-293

Williams EJ, Fischer DP, Noakes DE, England GCW, Rycroft A, Dobson H, Sheldon IM. 2007. The relationship between uterine pathogen growth density and ovarian function in the postpartum dairy cow. Theriogenology 68: 549-559.

Xing K, Chen XG, Liu CS, Cha DS, Park HJ. 2009. Oleoyl-chitosan nanoparticles inhibits Escherichia coli and Staphylococcus aureus by damaging the cell membrane and putative binding to extracellular or intracellular targets. Int J Food Microbiol 132: 127-133.

Zhang W, Sun J, Ding W, Lin J, Tian T, Liu X, Shen X, Qian PY. 2015. Extracellular matrix-associated protein form an integral and dynamic system during Pseudomonas aeruginosa biofilm development. Front Cell Infect Microbiol 5: 1-10.

Zhao LM, Shi LE, Zhang ZL, Chen JM, Shi DD, Yang J, Tang ZX. 2011. Preparation and application of chitosan nanoparticles and nanofibers. Braz J Chem Eng 28: 353-362. 